\title{
Appendix 1 Detailed description of computable general equilibrium model exercises and data matrices
}

In this research, we evaluate the importance of supply chains across Asia, especially as these help share the benefits of productivity, growth and higher incomes. What we see in today's global economy is a process of supply chain decomposition, where foreign direct investment (FDI) is distributing production tasks across an international matrix of intermediate producers. Individual components of this production matrix are chosen for a variety of reasons, including traditional Ricardian or HeckscherOhlin criteria (relative resource cost), market access, investment and/or administrative climate, and network externalities.

In Asia, this process has advanced very rapidly and pervasively, facilitated by both FDI and regional integration, where more advanced Asian economies reallocate production to less advanced ones. In the process of distributing supply chains, foreign investors in the region create new nodes of production (innovation clusters) in different localities, and with firms beginning as intermediate contractors and eventually producing and marketing their own brands. Under favorable conditions, industries and technology transfer can, as a result, replicate around the region at an unprecedented date.

To better understand the empirical significance of these phenomena, we use new data on the structure of regional industry and trade. To capture supply chains in terms of the trade of intermediate goods, we rely on the World Input-Output Database, which details domestic industrial structure, supply, demand, and trade for 35 commodities, including bilateral trade flows of both intermediate and final goods. This database currently exists for 41 countries, 27 of which are European Union members and six of which are in Asia (the People's Republic of China (PRC), India, Indonesia, Japan, the Republic of Korea and the Russian Federation). In addition to this data, we are using the Global Trade Analysis Project database to extend our sample of Asian countries, where World Input-Output 
Table A1.1 List of Asian economies modeled

\begin{tabular}{rlrrr}
\hline & & $\begin{array}{c}\text { GDP nominal } \\
\text { (USD millions) }\end{array}$ & $\begin{array}{c}\text { GDP PPP (USD } \\
\text { millions) }\end{array}$ & $\begin{array}{r}\text { GDP PC } \\
\text { (USD) }\end{array}$ \\
\hline 1 & PRC & 9181377 & 13395400 & 9844 \\
2 & Japan & 4901532 & 4698800 & 36899 \\
3 & India & 1870651 & 5069200 & 4077 \\
4 & Republic of Korea & 1221801 & 1666800 & 33189 \\
5 & Indonesia & 870275 & 1292900 & 5214 \\
6 & Taipei,China & 489213 & 929500 & 39767 \\
7 & Thailand & 387156 & 673700 & 9875 \\
8 & Malaysia & 312433 & 525700 & 17748 \\
9 & Singapore & 295744 & 348700 & 64584 \\
10 & Philippines & 272018 & 456400 & 4682 \\
11 & Viet Nam & 170565 & 359800 & 4012 \\
12 & Cambodia & 15659 & 39700 & 2576 \\
\hline
\end{tabular}

Notes: $\mathrm{GDP}=$ gross domestic product $\mathrm{PC}=$ per capita; $\mathrm{PPP}=$ purchasing power parity; PRC $=$ People's Republic of China; USD = United States' dollars.

Source: Global Trade Analysis Project (GTAP), www.gtap.org.

Database trade data are being used to impute intermediate trade. The result will be a final database with nearly twice the sectoral detail (57 instead of 35 ) and 12 leading Asian economies.

This new database will be used to calibrate Asian Regional CGE (ARC), a dynamic Asian regional CGE model with the regional detail shown in Table A1.1. These twelve economies comprise 95 percent of gross domestic product (GDP) in Central, East, South and Southeast Asia. Two more regional aggregates (the rest of South Asia and the rest of Southeast Asia) have also been included in the model.

The most authoritative and up-to-date source of data on trade in intermediate goods is the World Input-Output Database, a time series of world input-output tables for 41 countries worldwide and a model for the rest of the world, covering the period from 1995 to 2011. For our purposes, the World Input-Output Database is a starting point, but it only offers direct data on seven of the Asian economies listed in Table A1.1. Although these seven still comprise over 88 percent of Asian GDP, we would like to disaggregate the other five economies to investigate their potential to capture regional supply chain spillovers.

To accomplish this, we leveraged the Global Trade Analysis Project database (www.gtap.org), comprising detailed input-output and bilateral trade data for 118 countries and regions to 2007. The Global Trade 
Table A1.2 Economic structure of the Asian regional CGE model

\begin{tabular}{rlllll}
\hline & & Economy & & & Sector \\
\hline 1 & cam & Cambodia & 1 & agric & Agriculture \\
2 & chn & PRC & 2 & mining & Mining and Quarrying \\
3 & ind & India & 3 & foodpr & Food Processing \\
4 & idn & Indonesia & 4 & textap & Textile and Apparel \\
5 & jpn & Japan & 5 & woodpap & Wood and Paper Prod \\
6 & kor & Republic of Korea & 6 & fuels & Energy Fuels \\
7 & mys & Malaysia & 7 & chemical & Chemicals \\
8 & phl & Philippines & 8 & metal & Metal Products \\
9 & sgp & Singapore & 9 & machinery & Machinery \\
10 & twn & Taipei,China & 10 & electronics & Electronic and Optical \\
11 & tha & Thailand & 11 & vehicles & Transport Vehicles \\
12 & vnm & Viet Nam & 12 & othermfg & Other Manufactures \\
13 & xsa & Other S Asia & 13 & utilities & Electric, Gas, and Water \\
& & & & & Utilities \\
14 & xse & Other SE Asia & 14 & construct & Construction \\
15 & rus & The Russian Federation & 15 & whretrade & Wholesale and Retail Trade \\
16 & eur & EU27 & 16 & transport & Transport Services \\
17 & usa & United States & 17 & telcomm & Post and Telecom Services \\
18 & bra & Brazil & 18 & fininsre & Finance, Insurance, Real \\
& & & & & Estate \\
19 & lac & Latin America & 19 & othprvsrv & Other Private Services \\
20 & row & Rest of World & 20 & publicsrv & Public Administration \\
\hline & & & & &
\end{tabular}

Note: $\quad$ PRC $=$ People's Republic of China $; \mathrm{EU}=$ European Union; $\mathrm{S}=$ South $; \mathrm{SE}=$ Southeast.

Source: Global Trade Analysis Project (GTAP), www.gtap.org.

Analysis Project data are recorded at a 57-sector aggregation, which we have bridged to the World Input-Output Database's data using comparisons of countries covered in both databases. Based on this correspondence, we then disaggregate import flows for the other five Asian economies we wanted to include in the regional model. For practical dynamic scenario work, we then aggregated all country structure and trade flows to 20 sectors, yielding the economic structure summarized in Table A1.2.

The advantage of explicitly modeling intermediate trade is to capture the network spillover effects that reach across geographic boundaries and sectors in the region, conferring productivity and other growth benefits as a by-product of regional cooperation and integration (RCI). The complexity of these linkages is such that it would be quite impossible for policy makers or trade negotiators to anticipate them by intuition alone. Such 'general 
equilibrium' growth linkages are responsible for a large and growing share of international value creation and factor employment and/or income. For this reason, the conventional view of gains from trade in final goods and services seriously understates the economic potential of RCI.

Global supply networks have leveraged the world's resource base and a more liberal trading environment to increase incomes in ways more pervasive than most of us can imagine, and broadening the basis for these activities can only amplify these benefits, distribute them more widely, and reduce the risks of economic concentration and instability. The approach here strengthens the evidence of these network effects and improves visibility about them for policy makers. Our analysis is designed to reveal the complex indirect linkages in Asian RCI trading systems, largely mediated by intermediate supply and intra-industry trade. These can often represent the majority of value creation, and also form the basis for productivity and growth spillovers.

\section{SCENARIO DEVELOPMENT}

The baseline is a status quo or 'business-as-usual' scenario, where we assume national and multilateral policy regimes are not changed and no external shocks occur. Under these conditions, steady aggregate growth and moderate structural change are to be expected, yet a modern history of the Asian region has been much more dynamic. The difference has been due to a combination of public and private agency, with the former providing reformist guidance and the latter responding quickly to changing opportunities and challenges. To capture these events in a forecasting framework, we specify counterfactual policy scenarios we are interested in, using simulation analysis to predict how private actors across the region will respond according to the economic theory embodied in the CGE model (see Table A1.3).

One of the hallmarks of Asia's modern growth experience has been technological progress and skill development. The most dynamic regional economies have all promoted productivity growth effectively, achieving some of the world's highest rates of total factor productivity growth (see Figure A1.1). Capital productivity generally increased through determined public-private partnerships for industrial modernization and technology transfer. At the same time, the most dynamic economies intensified and extended their early commitments to education and promotion of skillintensive employment, first in manufacturing and eventually in higher value-added service sectors. The product of these strategies, in the most successful cases, has been a dramatic expansion of the middle classes, with 
Table A1.3 Scenario menu

\begin{tabular}{|c|c|c|}
\hline & Scenario Class & Characteristics \\
\hline 1 & Baseline & Baseline ('business-as-usual') scenario \\
\hline 2 & EU Lost Decade & $\begin{array}{l}\text { Assume baseline growth elsewhere, but the } \\
\text { European Union economies average zero growth, } \\
2015-25\end{array}$ \\
\hline 3 & PRC Hard Landing & $\begin{array}{l}\text { Assume the PRC averages 5\% real GDP growth, } \\
2015-25\end{array}$ \\
\hline 4 & Skills & $\begin{array}{l}\text { Assume baseline conditions, but also that } \\
\text { Asian economies sustain growth rates of labor } \\
\text { productivity as indicated in Figure A1.1, with rates } \\
\text { for all countries converging to the regional average } \\
\text { by } 2030 \text {. }\end{array}$ \\
\hline 5 & Technology & $\begin{array}{l}\text { Assume the skills scenario, but also that the } \\
\text { Asian economies sustain growth rates of capital } \\
\text { productivity as indicated in Figure A1.1, with rates } \\
\text { for all countries converging to the regional average } \\
\text { by } 2030 \text {. }\end{array}$ \\
\hline 6 & ASEAN plus 3 & $\begin{array}{l}\text { In addition to Scenario 5, assume the regions } \\
\text { achieve conformity with an ASEAN plus } 3 \text { Free } \\
\text { Trade Agreement }\end{array}$ \\
\hline 7 & Infrastructure & $\begin{array}{l}\text { In addition to Scenario } 6 \text {, assume that investments } \\
\text { and institutional changes effect a } 50 \% \text { reduction } \\
\text { in average trade, transport and transit margins for } \\
\text { lower-income Asian countries. }\end{array}$ \\
\hline 8 & Financial Integration & $\begin{array}{l}\text { In addition to Scenario } 7 \text {, assume that, for low- } \\
\text { income Asian economies, the stock of FDI rises to } \\
\text { at least } 10 \% \text { of GDP by } 2030 \text {. }\end{array}$ \\
\hline
\end{tabular}

Notes: $\quad$ ASEAN $=$ Association of Southeast Asian Nations; EU = European Union; FDI $=$ foreign direct investment; GDP $=$ gross domestic product; $P R C=$ People's Republic of China.

Source: Scenarios developed by David Roland-Holst (2015).

their attendant capacity for self-sustaining domestic growth and expanding public goods and services.

To examine how national and regional policy initiatives can advance and expand long-term Asian prosperity we consider eight representative policy scenarios, summarized in Table A1.3; the results appear in Table A1.4. These fall into three general categories: risks of adverse growth trends, productivity improvements, and private sector promotion. Under the two productivity growth scenarios, we assume that Asian economies return to 


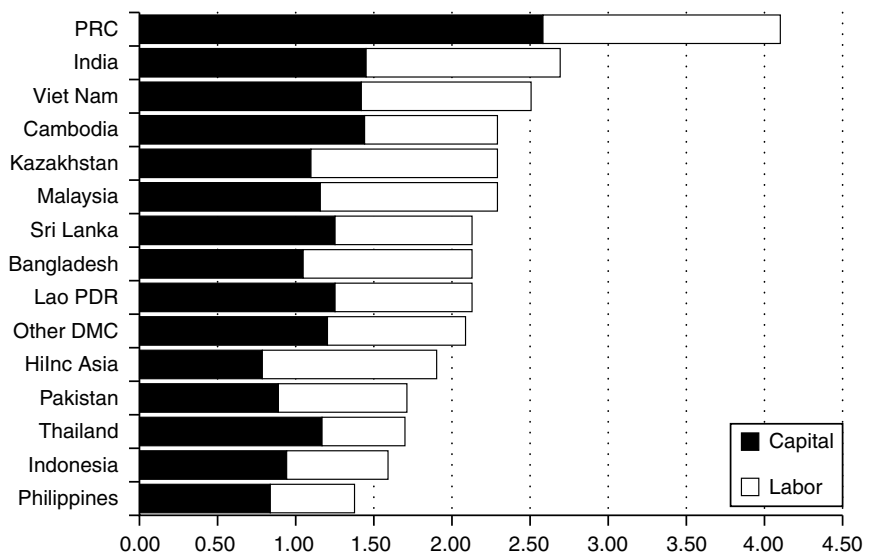

Notes: $\quad$ PRC $=$ People's Republic of China $;$ DMC $=$ developing member country (of the Asian Development Bank); HiInc Asia = high income Asia; Lao PDR = Lao People's Democratic Republic.

Sources: International Labor Organization (ILO) (2000-10); Iyar and Dalgaard (2005); Young (1995).

Figure A1.1 Labor and capital productivity growth in Asia, 1999-2008 (\% per annum)

their pre-global-financial-crisis trajectories of productivity growth. We also assume that long-term growth disparities among Asian economies decline, and, in such scenarios, productivity levels converge to regional averages by 2030 . Then we decompose factor productivity growth, attributing capital productivity growth to technological change, and labor productivity growth to skill increase and technology.

Successful Asian economies have been technology-driven and continually striving to upgrade the skills of their population. The benefits of this human resources approach to growth and development become even more pronounced with the application of regional policies that facilitate trade and capital flows. Thus, we see that national investments in human resources can contribute to growth, but their full potential can only be realized with complementary financial investment. This is true regardless of the source of the investment, a fact that should not be ignored by countries that have not committed fully to a favorable investment climate. In these circumstances, every public dollar spent on human capital is underperforming without the complementary private dollar to enhance productivity - directly via on-the-job training, and indirectly via technology infusion. 
Table A1.4 Average wage growth (\% change from baseline in 2030: cumulative over scenarios)

\begin{tabular}{lccccccr}
\hline & EURHL & PRCHL & Skills & Tech & APlus3 & Infra & FDI \\
\hline PRC & -2 & -14 & 13 & 40 & 39 & 47 & 65 \\
Indonesia & -5 & -5 & 9 & 38 & 38 & 52 & 101 \\
India & -2 & -1 & 12 & 37 & 35 & 43 & 90 \\
Japan & -1 & -2 & 11 & 28 & 37 & 46 & 50 \\
Cambodia & -2 & 0 & 3 & 28 & 26 & 44 & 116 \\
Republic of Korea & 1 & 1 & 8 & 27 & 31 & 42 & 47 \\
Malaysia & 0 & 0 & 8 & 41 & 42 & 59 & 64 \\
Philippines & 0 & -2 & 5 & 42 & 39 & 54 & 131 \\
Singapore & 0 & 0 & 8 & 33 & 35 & 44 & 52 \\
Thailand & -3 & -8 & 7 & 50 & 54 & 74 & 120 \\
Taipei,China & -2 & -7 & 17 & 34 & 30 & 40 & 45 \\
Viet Nam & -5 & -2 & 9 & 35 & 43 & 67 & 108 \\
Other S Asia & -7 & -1 & 7 & 24 & 23 & 28 & 111 \\
Other SE Asia & -3 & -2 & 7 & 49 & 44 & 59 & 126 \\
All Asia & -1 & -2 & 11 & 32 & 34 & 44 & 53 \\
\hline
\end{tabular}

Notes: $\quad$ APlus3 $=$ ASEAN +3 (Scenario 6 from Table A1.3); PRC $=$ People's Republic of China; PRCHL = PRC Hard Landing (Scenario 3 from Table A1.3); EURHL = European Union Hard Landing (Scenario 3 from Table A1.3); FDI = (Scenario 8 from Table A1.3); Infra $=($ Scenario 7 from Table A1.3 $) ; \mathrm{S}=$ South; $\mathrm{SE}=$ Southeast.

Source: Author.

Conversely, countries that merely invite capital investment without making their own financial commitments to human capital development will be trapped in long-term structural bias toward resource-extractive, low-valueadded, low-wage production. 